\title{
VOCALS-CUpEx: the Chilean Upwelling Experiment
}

\author{
R. D. Garreaud ${ }^{1}$, J. A. Rutllant ${ }^{1,2}$, R. C. Muñoz ${ }^{1}$, D. A. Rahn ${ }^{1}$, M. $\operatorname{Ramos}^{2,3}$, and D. Figueroa ${ }^{4}$ \\ ${ }^{1}$ Department of Geophysics, Universidad de Chile, Santiago, Chile \\ ${ }^{2}$ Center for Advanced Studies in Arid Zones (CEAZA), La Serena, Chile \\ ${ }^{3}$ Facultad de Ciencias del Mar, Universidad Católica del Norte, Coquimbo, Chile \\ ${ }^{4}$ Department of Geophysics, Universidad de Concepción, Concepción - Chile
}

Received: 14 October 2010 - Published in Atmos. Chem. Phys. Discuss.: 5 November 2010

Revised: 31 January 2011 - Accepted: 18 February 2011 - Published: 4 March 2011

\begin{abstract}
The VAMOS Ocean-Cloud-Atmosphere-Land Study Regional Experiment (VOCALS-REx) was a major field experiment conducted in spring of 2008 off southern Peru and northern Chile, aimed at better understanding the coupled climate systems of the southeast Pacific. Because of logistical constrains, the coastal area around $30^{\circ} \mathrm{S}$ was not sampled during VOCALS-REx. This area not only marks the poleward edge of the subtropical stratocumulus cloud regime (thus acting as a source of transient disturbances) but is also one of the most active upwelling centers and source of surface ocean kinetic energy along the Chilean coast. To fill such an observational gap, a small, brief, but highly focused field experiment was conducted in late spring 2009 in the near-shore region around $30^{\circ} \mathrm{S}$. The Chilean Upwelling Experiment (CUpEx) was endorsed by VOCALS as a regional component.

CUpEx included long-term monitoring, an intensive twoweek field campaign and off-shore research flights. Our goal was to obtain an atmospheric/oceanic dataset with enough temporal and spatial coverage to be able to document (a) the mean diurnal cycles of the lower-troposphere and upper-ocean in a region of complex topography and coastline geometry, and (b) the ocean-atmosphere response to the rapid changes in coastal winds from strong, upwelling-favorable equatorward flow (southerly winds) to downwelling-favorable poleward flow (northerly winds). In this paper we describe the measurement platforms and sampling strategy, and provide an observational overview, highlighting some key mean-state and transient features.
\end{abstract}

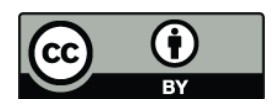

Correspondence to: R. D. Garreaud (rgarreau@dgf.uchile.cl)

\section{Background and goals}

The VAMOS Ocean-Cloud-Atmosphere-Land Study (VOCALS) is an international program aimed at improving the understanding of the subtropical Southeast Pacific (SEP) coupled ocean-atmosphere-land system on diurnal to interannual timescales (Mechoso and Wood, 2010). To address the many VOCALS science questions a major regional experiment, VOCALS-REx, was carried out during October and November 2008 off northern Chile and southern Peru (Fig. 1), including an unprecedented number of atmospheric and oceanographic measurements taken concurrently from five aircraft, two research vessels and two land sites (Wood et al., 2011). It was originally planned that VOCALS-REx would include a coastal component encompassing the nearshore region down to about $30^{\circ} \mathrm{S}$. Because of logistical constraints, however, most of the field work during VOCALSREx took place between $25^{\circ} \mathrm{S}$ and $16^{\circ} \mathrm{S}$. About a year later, several Chilean institutions (Table 1) teamed up to conduct an additional field experiment to fill the observational gap. The Chilean Upwelling Experiment (CUpEx) was endorsed by VOCALS as a regional component focused on the atmosphere-ocean dynamics that characterize the nearshore $(0-100 \mathrm{~km})$ region off north-central Chile. The objectives, methodology and platforms used in CUpEx are coincident with field experiments conducted in other eastern boundary upwelling systems (summarized in Table 2; see also Smith, 1992), especially along the west coast of North America.

The lower-troposphere/upper-ocean off north-central Chile exhibits the archetypical structure of the eastern boundary of subtropical oceans (e.g., Bakun and Nelson, 1991; Klein and Hartmann, 1993) and is part of the Humboldt upwelling system along the west coast of South America. Specifically, the coastal area targeted by CUpEx $\left(\sim 31-29^{\circ} \mathrm{S}\right.$, Fig. 2$)$ marks the transition between an extremely stable and dry region to the north (dominated by the SEP anticyclone, Fig. 3a) and a more synoptically

Published by Copernicus Publications on behalf of the European Geosciences Union. 


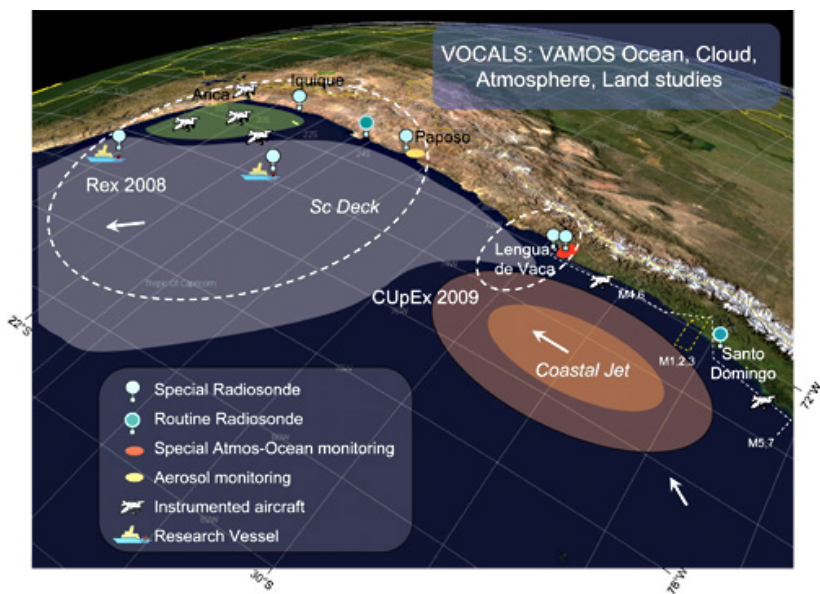

Fig. 1. An overview of the areas targeted by and platforms employed in the VOCALS field experiments. VOCALS-REx took place in October-November 2008 in a large coastal and open ocean area off southern Perú and northern Chile (down to $25^{\circ} \mathrm{S}$ ), including two research vessels, five fully instrumented aircrafts and one land supersite (Paposo). VOCALS-CUpEx took place in NovemberDecember 2009 in the coastal area around $30^{\circ} \mathrm{S}$ (Lengua de Vaca and the bay of Tongoy) and included 7 research missions off central Chile during 2010/2011 (M1-M7). The map also shows some key locations and atmospheric features over the southeast Pacific: the stratus cloud deck, the coastal low-level jet and the southerly flow around the subtropical anticyclones.

active region to the south with frequent passage of eastward migrating weather systems. The southern edge of the SEP stratocumulus ( $\mathrm{Sc}$ ) deck is roughly at $30^{\circ} \mathrm{S}$ (e.g., Painemal et al., 2010; see also Fig. 3c) and the exit region of the atmospheric low-level jet along the Chilean coast is often located at this latitude (Garreaud and Muñoz, 2005; see also Fig. 3b). Consistently, the region around $30^{\circ} \mathrm{S}$ is recognized as one of the most active upwelling centers in Chile and as a source of ocean kinetic energy along the Chilean coast, especially during springtime (Rutllant and Montecino, 2002; Hormazabal et al., 2004). Likewise, the adjacent coastal area exhibits one of the largest wind-energy potentials in Chile (Muñoz et al., 2003) and fog sustains diverse plant communities in the coastal mountains (e.g, Del-Val et al., 2006). In addition to regional climate issues, CUpEx is important in a broader context, as many of the transient features that populate the subtropical SE Pacific are originated along the semiarid coast of Chile and subsequently advected offshore (e.g., Rahn and Garreaud, 2010a).

Broadly speaking, the coastline, coastal range and Andes cordillera are oriented in a north-south direction along subtropical latitudes, rendering a nearly two dimensional atmosphere-ocean system. A closer inspection, however, reveals a more complex structure, including four major points (see Fig. 3b): Lavapie $\left(36^{\circ} \mathrm{S}\right)$, Lengua de Vaca (LdV, $\left.30^{\circ} \mathrm{S}\right)$, Choros $\left(28.5^{\circ} \mathrm{S}\right)$ and Angamos on the northern edge of the

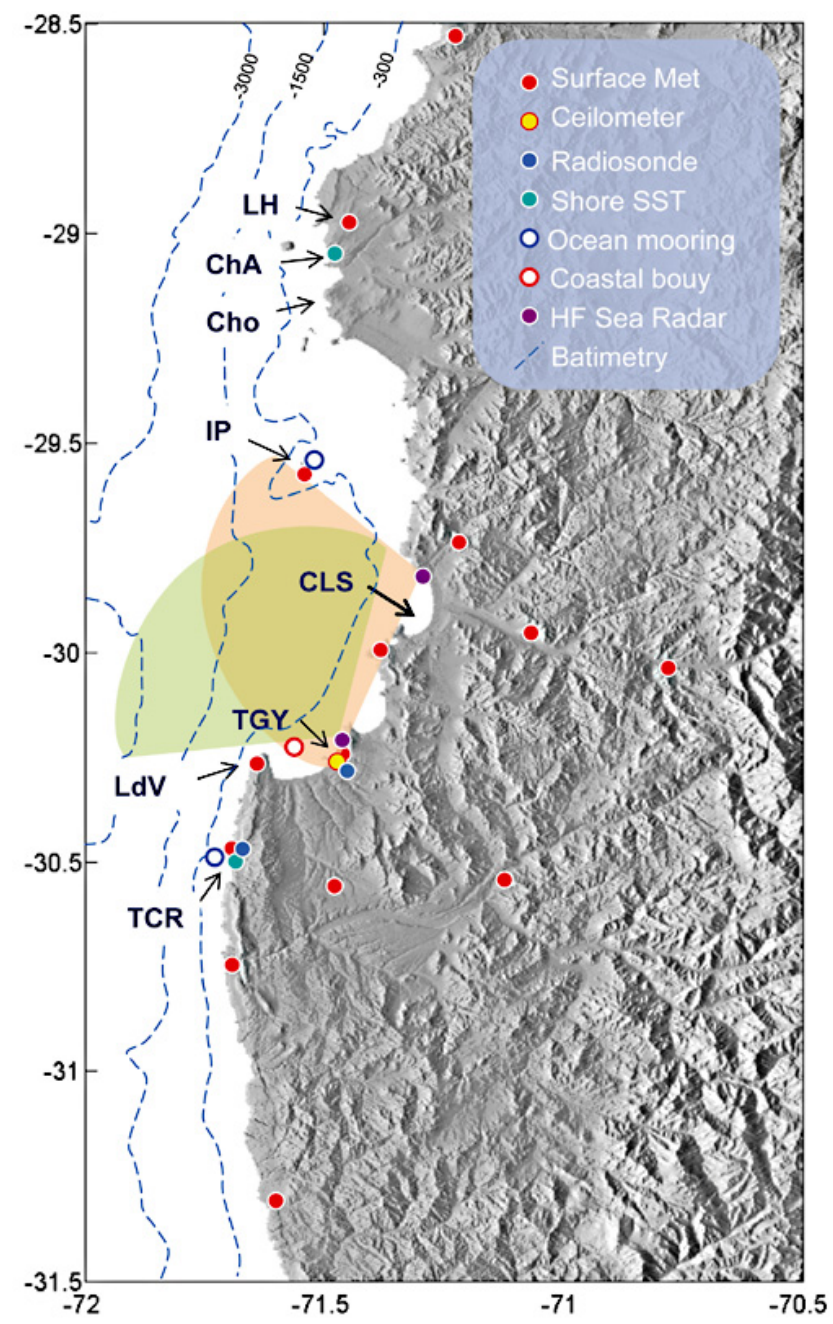

Fig. 2. Shaded relief of the coastal CUpEx area. Coastal mountains are about $500 \mathrm{~m}$ high. Relevant locations are TCR $=$ Talcaruca, $\mathrm{LdV}=$ point Lengua de Vaca, TGY = Tongoy (town), CLS: Coquimo and La Serena cities, IP = Islote Pajaros, Cho = point Choros, $\mathrm{ChA}=$ Chañaral de Aceituno, $\mathrm{LH}=$ Loma de Hueso. Also shown is the location of the meteorological and oceanographic measurement systems (color code in the inset). The light orange and green sectors indicate the area covered by the HF Sea Radars at La Serena and Tongoy, respectively. Blue, dashed lines indicate ocean floor depth (in meters).

Mejillones Peninsula $\left(23^{\circ} \mathrm{S}\right)$. South of these points the coastline is straight north-south. North of these points the coastline sharply retracts eastward a few tens of kilometers, forming wide, northwest-facing embayments. The complexities in the coastline geometry and adjacent topography are reflected in several surface-ocean and low-tropospheric fields. Points Lengua de Vaca, Choros and Lavapie are recognized as the most active upwelling centers along the Chilean coast during spring and summer (e.g., Strub et al., 1998; Figueroa and Moffat, 2000). The intense upwelling is driven by 
(a) SLP \& 10-m winds

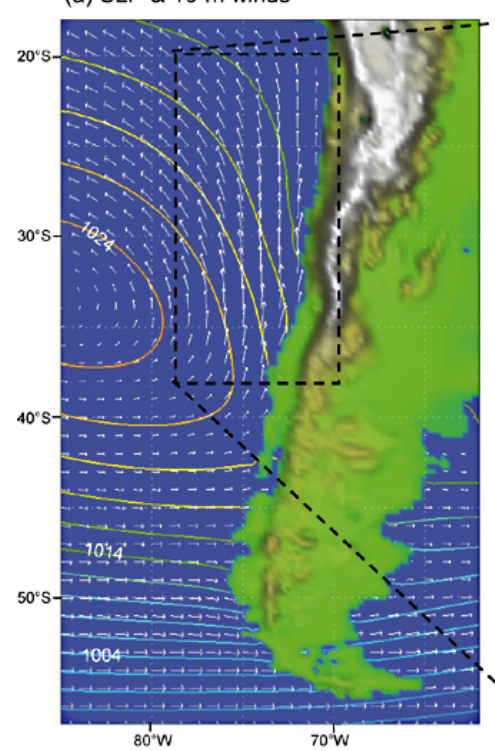

(b) Surface wind speed

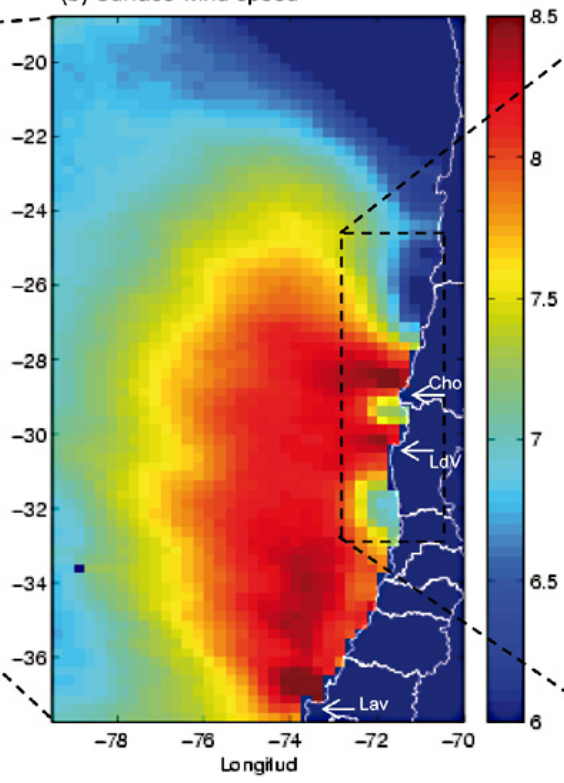

(c) Cloud fraction

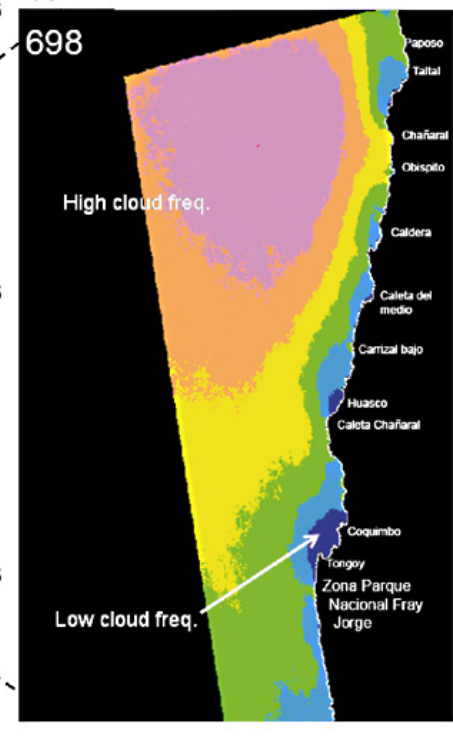

Fig. 3. (a) Spring-Summer (SONDJF) average of sea level pressure (contoured every $2 \mathrm{hPa}$ ) and 10-m wind vectors (arrows) off the Chilean coast. Data source: NCEP-NCAR reanalysis. (b) Spring-Summer (SONDJF) average of surface wind speed derived from 4 yr of QuikScat observations. Color scale at right in $\mathrm{m} \mathrm{s}^{-1}$. Note the near coastal jets off points Choros (Cho), Lengua de Vaca (LdV) and Lavapie (Lav). Adapted from Garreaud and Muñoz (2005). (c) Spring (SON) climatology of low cloud frequency derived from visible GOES imagery (pink is $>80 \%$; blue is less than $30 \%$ ). Adapted from Gonzalez et al. (2007).

Table 1. List of projects and institutions supporting VOCALS-CUpEx.

\begin{tabular}{lll}
\hline Platform/Instruments & PIs & Funding \\
\hline AIMMS-20 on BE90 & R. Garreaud (DGF) & FONDECYT-Grant 1090492, DGF-UCH, DGAC \\
$\begin{array}{l}\text { AWS, Radiosondes at Tongoy and Talcaruca } \\
\text { Tongoy bay buoy and AWS Islote Pajaros }\end{array}$ & J. Rutllant (DGF) R. Muñoz (DGF) & FONDECYT-Grant 1090492, DMC, CNE, DGF-UCH \\
Surface Current Radars & Dante Figueroa (DGEO) & CEAZA, INOVA-CORFO 07CN13IXM-150, \\
Ocean moorings & FONDECYT 1080606 \\
\hline
\end{tabular}

DGF: Department of Geophysics, Universidad de Chile, DGEO: Department of Geophysics, Universidad de Concepción, CEAZA: Centro de Estudios Avanzados de Zonas Áridas, DGAC: Dirección General de Aeronáutica Civil, DMC: Dirección Meteorológica de Chile, CNE: Comisión Nacional de Energía

localized southerly wind ${ }^{1}$ maxima around these points (as detected by mean QuickSCAT surface winds; Fig. 3a) that are connected with a broader southerly low-level jet offshore (Garreaud and Munoz, 2005). Satellite imagery also reveals a spatial sequence of cloudy and clear areas (Fig. 3c) with the lowest (highest) cloud frequencies consistently located downstream (upstream) of the coastal points, suggesting alongshore variability in the atmospheric marine boundary layer $(\mathrm{AMBL})$ structure.

\footnotetext{
${ }^{1}$ In this paper wind direction is always expressed as from in meteorological convention. For instance, southerly winds (southerlies) indicate wind blowing from the South (equatorward flow in the SH).
}

In CUpEx we have focused our observations around point LdV, including the bays of Tongoy and Coquimbo (Fig. 2, Table 3), but we hope that some of the findings here can be extrapolated to other point/bay complexes in Chile and elsewhere. Despite its proximity to land, processes embedded in this near-coastal strip have been poorly documented because of lack of in-situ observational platforms (including the absence of routine radiosondes) and near-shore limitations that result from land mask and resolution in microwave SSTs and scatterometer. Therefore, CUpEx included longterm monitoring, an intensive two-week field campaign and off-shore research flights. Our goal was to obtain an atmospheric/oceanic dataset with enough temporal and spatial resolution, as well as coverage, to be able to document: 
Table 2. Summary of selected meteorological/oceanography experiments conducted in eastern boundary upwelling systems.

\begin{tabular}{|c|c|c|c|}
\hline Experiment Name & Target region & Period* & Key reference \\
\hline Coastal Upwelling Experiment I (CUE-I) & Oregon central coast $\left(\sim 42^{\circ} \mathrm{N}\right)$ & August 1972 & Hawkins and Stuart (1980) \\
\hline JOINT I & Canary/northern Africa coast $\left(21^{\circ} \mathrm{N}\right)$ & Spring 1974 & Mittelstaedt et al. (1975) \\
\hline CUEA JOINT-II & Peruvian coast $\left(12-15^{\circ} \mathrm{S}\right)$ & Spring 1976 & Brink et al. (1978) \\
\hline Coastal Ocean Dynamics Exp. (CODE) & California coast $\left(\sim 38^{\circ} \mathrm{N}\right)$ & $\begin{array}{l}\text { Spring-summer } \\
1981 \text { and } 1982\end{array}$ & Beardsley et al. (1987) \\
\hline Leeuwin Current Interdisciplinary Exp. (LUCIE) & Western Australia $\left(21-33^{\circ} \mathrm{S}\right)$ & $1986-1987$ & Smith et al. (1991) \\
\hline Southern Benguela Experiment & Southern Benguela coast $\left(32^{\circ} \mathrm{S}\right)$ & Fall 1987 & Bailey and Chapman (1991) \\
\hline Shelf Mixed Layer Experiment (SMILE) & Northern California coast $\left(39^{\circ} \mathrm{N}\right)$ & Winter 1989 & Dorman and Winant (1995) \\
\hline Coastal Waves (CW96) & Central California coast $\left(37^{\circ} \mathrm{N}\right)$ & Summer 1996 & Rogers et al. (1998) \\
\hline Autonomous Ocean Sensing Network (AOSN) & Monterey Bay, California coast $\left(36^{\circ} \mathrm{N}\right)$ & Summer 2000 & Ramp et al. (2005) \\
\hline VOCALS-Rex Perú Cruise & Central Peruvian coast $\left(14-16^{\circ} \mathrm{S}\right)$ & Spring 2008 & Grados et al. (2010) \\
\hline VOCALS-CUpEx & Central Chile coast $\left(30^{\circ} \mathrm{S}\right)$ & Spring 2009 & Garreaud et al. (2010) and this work \\
\hline
\end{tabular}

* Season relative to target region.

Table 3. Platforms and instrument available during CupEx.

\begin{tabular}{|c|c|c|c|c|}
\hline \multicolumn{5}{|c|}{ a. Talcaruca $\left(30.48^{\circ} \mathrm{S}, 71.70^{\circ} \mathrm{W}, 10 \mathrm{~m}\right.$ a.s.1.) } \\
\hline Platform/Instrument & Variables & $\begin{array}{l}\text { Recording } \\
\text { interval }\end{array}$ & Operation Period & Comments \\
\hline AWS & $T_{\mathrm{a} 2}, \mathrm{RH}_{2}, P_{\mathrm{s}}, V_{4}, \mathrm{SR}, \mathrm{NR}$ & $15 \mathrm{~min}$ & 20 Nov 2009 - Present & \\
\hline Radiosonde & $T_{\mathrm{a}}, T_{\mathrm{d}}, V, p$ & $\Delta z \sim 3 \mathrm{~m}$ & 21 Nov-5 Dec 2009 & Launches at 08:30 and 17:30 LT \\
\hline Shore SST & SST & $10 \mathrm{~min}$ & Mar 2001-Present & \\
\hline Coastal mooring & $T_{\mathrm{o}}, S, V_{\mathrm{o}} 10-100 \mathrm{~m}$ & $60 \mathrm{~min}$ & Jun 2008-Present & $2 \mathrm{~km}$ off the coast \\
\hline \multicolumn{5}{|c|}{ b. Tongoy beach $\left(30.26^{\circ} \mathrm{S}, 71.63^{\circ} \mathrm{W}, 15 \mathrm{~m}\right.$ a.s.1.) and bay buoy $\left(30.25^{\circ} \mathrm{S}, 71.55^{\circ} \mathrm{W}\right)$} \\
\hline Platform/Instrument & Variables & $\begin{array}{l}\text { Recording } \\
\text { interval }\end{array}$ & Operation Period & Comments \\
\hline AWS & $T_{\mathrm{a} 2}, \mathrm{RH}_{2}, P_{\mathrm{S}}, V_{4}, \mathrm{SR}, \mathrm{NR}$ & $15 \mathrm{~min}$ & 21 Nov-5 Dec 2009 & \\
\hline Ceilometer & Cloud base height & $15 \min$ & 15 Oct-5 Dec 2009 & \\
\hline Radiosonde & $T_{\mathrm{a}}, T_{\mathrm{d}}, V, p$ & $\Delta z \sim 30 \mathrm{~m}$ & 21 Nov-5 Dec 2009 & Launches at 08:30 and 17:30 LT \\
\hline AWS-buoy & $T_{\mathrm{a} 2}, \mathrm{RH}_{2}, P_{\mathrm{s}}, V_{2}, \mathrm{SR}$ & $60 \mathrm{~min}$ & Jun 2008-Present & \\
\hline Mooring-buoy & $T_{\mathrm{O}}, S$ at $5 \mathrm{~m}$ & $60 \mathrm{~min}$ & Jun 2008-Present & $2.3 \mathrm{~km}$ off the coast \\
\hline \multicolumn{5}{|c|}{ c. Other automatic weather stations } \\
\hline Site & \multicolumn{2}{|c|}{ Lat-Lon-Lev } & Variables & Operation Period \\
\hline Caleta Toro & \multicolumn{2}{|c|}{$30.72^{\circ} \mathrm{S}, 71.70^{\circ} \mathrm{W}, 12 \mathrm{~m}$ a.s.1. } & $V_{10}$ & Mar 2008-Present \\
\hline Point Lengua de Vaca & \multicolumn{2}{|c|}{$30.25^{\circ} \mathrm{S}, 71.62^{\circ} \mathrm{W}, 17 \mathrm{~m}$ a.s.l. } & $T_{\mathrm{a} 2}, \mathrm{RH}_{2}, P_{\mathrm{S}}, V_{4}, \mathrm{SR}$ & Mar 1990-Present \\
\hline Islote Pajaros & \multicolumn{2}{|c|}{$29.58^{\circ} \mathrm{S}, 71.55^{\circ} \mathrm{W}, 5 \mathrm{~m}$ a.s.l. } & $V_{4}$ & Oct 2009-Present \\
\hline Loma de Hueso & \multicolumn{2}{|c|}{$28.91^{\circ} \mathrm{S}, 71.45^{\circ} \mathrm{W}, 187 \mathrm{~m}$ a.s.l. } & $V_{10}$ & Jun 2006-Present \\
\hline
\end{tabular}

$T_{\mathrm{a} 2}$ : Air temperature at $2 \mathrm{~m}$ a.g.l., $\mathrm{RH}_{2}$ : Relative humidity at $2 \mathrm{~m}$ a.g.l., $P_{\mathrm{S}}$ : Surface pressure, $V \mathrm{x}$ : wind speed and wind direction at $\mathrm{x} \mathrm{m}$ a.g.l. $(\mathrm{x}=2$, 4 or $10 \mathrm{~m}$ ), SR: Global solar radiation, NR: Net radiation, $T_{0}$ : Ocean temperature, $S$ : Salinity, $V_{0}$ : Ocean currents (speed and direction).

- the regional-scale, mean diurnal cycle of the near-shore surface winds and its impact on ocean currents and SST;

- the mean structure and alongshore variability of the lower troposphere at $30^{\circ} \mathrm{S}$ with emphasis in the cloud topped AMBL;
- the lower-troposphere and upper-ocean response to the rapid changes in coastal winds from strong, upwellingfavorable southerly winds to relaxed southerlies or even weak downwelling favorable northerlies. 
It turned out that the two-week intensive observations during CUpEx included an 8-day period of remarkably similar meteorological conditions (well suited to document the mean diurnal cycles) bounded by two, well-defined transitions from high-to-low winds (well suited to characterize synoptic variability). In this paper we provide a description of CUpEx platforms and operations (Sect. 2), an overview of the main observational results including synoptic-scale changes (Sect. 3) and the mean diurnal cycle (Sect. 4).

\section{Experimental setup}

The CUpEx intensive field campaign was centered on point Lengua de Vaca (LdV) and the bay of Tongoy ( $30^{\circ} \mathrm{S}$, Fig. 2), from 21 November to 5 December 2009 (late austral spring). These dates are within the climatological period of maximum southerly winds in this region (Muñoz, 2008). Although a moderate central Pacific El Niño event developed during the second semester of 2009 - and many indices peaked by the end of the year - conditions along the coast of north-central Chile remained near average during CUpEx. Slightly cold (less than $0.25^{\circ} \mathrm{C}$ ) SST anomalies prevailed off the subtropical west coast of South America; the SEP anticyclone had near-average values and was centered near its climatological position $\left(30^{\circ} \mathrm{S} 100^{\circ} \mathrm{W}\right)$ for austral spring. The following instruments and platforms were in place during CUpEx (Fig. 2, Table 3):

\subsection{Surface meteorology and radiosondes}

Surface meteorology (2-m air temperature and relative humidity, barometric pressure, $3-\mathrm{m}$ wind and solar radiation) was recorded every $15 \mathrm{~min}$ in 5 automatic weather stations (AWS) along the coast between $31^{\circ}$ and $28^{\circ} \mathrm{S}$, in a buoy at the mouth of Tongoy bay, and at Islote Pajaros $30 \mathrm{~km}$ off the coast (Table 3, Fig. 2). Three of these stations (Talcaruca, Tongoy and Islote Pajaros) were installed at the beginning of CUpEx; the other stations belong to permanent networks and provide a long-term context to CUpEx results. The AWS at Tongoy was complemented with a laser ceilometer providing cloud frequency and cloud base height every minute.

During CUpEx radiosondes were lauched at 08:30 and 17:30 LT (11:30 and 20:30 UTC) at Talcaruca (upstream of Point LdV), using InterMet iMet-1 sondes, and Tongoy (downstream of Point LdV), using Vaisala RS80-15G sondes. The radiosondes aimed at capturing the differences in low-level circulation within and above the AMBL between the straight-coastline sector and the bay of Tongoy at the extremes of the diurnal cycle. They also provided the first systematic tropospheric observations at $30^{\circ} \mathrm{S}$ in the coastal area. The nearest routine radiosondes are launched at 12:00 UTC by the National Weather Service at Santo Domingo $\left(33.5^{\circ} \mathrm{S}\right)$ and Antofagasta $\left(23^{\circ} \mathrm{S}\right)$.

\subsection{Sea temperature and currents}

Shoreline sea temperature has been recorded for several years every $10 \mathrm{~min}$ in Talcaruca and Chañaral de Aceituno (Fig. 2; Tapia et al., 2009). The instruments are located $\sim 1 \mathrm{~m}$ below the mean lower low water in the rocky subtidal substratum, thus being a good proxy of local SST (Tapia et al., 2009). Before, during and after CUpEx, ocean temperature was recorded hourly in a coastal mooring $2.2 \mathrm{~km}$ off Talcaruca at 5, 10, 15, 20, 25, 30, 40, 50, 70, 90, $110 \mathrm{~m}$ depth using Hobo Water Temp Pro-V2 thermometers. Sea temperature was also recorded at $5 \mathrm{~m}$ below the surface at the Tongoy buoy. Ocean currents were recorded hourly with 4-m horizontal resolution using ADCPs (Acoustic Doppler Profiler) RDI- $300 \mathrm{kHz}$ anchored over the continental shelf off Talcaruca and near Islote Pajaros.

A pair of WERA high-frequency radars (Fig. 2) was installed near Tongoy and to the north of Coquimbo, operating from early October to the end of the CUpEx period. The radar pulse has a frequency of $22.5 \mathrm{MHz}$ (wavelength $\sim 13 \mathrm{~m}$ ) to maximize the return from surface waves within about $40 \mathrm{~km}$ offshore. Spectral analysis of the return signal allows determining radial surface current speeds and wave spectra. Further, surface currents and wind direction can be obtained in the area simultaneously covered by the two radars. The two radar configuration used during CUpEx produces an overlap area over much of the bay of Tongoy (Fig. 2), where data was obtained every $20 \mathrm{~min}$ at a $300 \mathrm{~m}$ horizontal resolution.

\subsection{Airborne measurements}

To complement the coastal observations and explore the offshore AMBL structure, airborne meteorological observations were (and still are) conducted off the central Chile coast (Fig. 1). To this purpose, we installed an Aircraft Integrated Meteorological Measurement System (AIMMS-20) under the right wing of a Beechcraft King Air BE-90. The aircraft belongs to the Chilean Civil Aviation Directorate (DGAC) and its two turboprops provide a range of more than $2500 \mathrm{~km}$. The AIMMS-20 measures air temperature, relative humidity, wind speed and direction (three components), pressure and aircraft position (latitude-longitude-elevation) at $1 \mathrm{~Hz}$. The AIMMS-20 was developed by Aventech Inc. in Canada and it has been used by meteorology research groups at the University of Manchester, UK (Beswick et al., 2007) and Duke University, USA (Avissar et al., 2009). At the time of writing this paper we have performed seven scientific missions off central Chile described online at http: //www.dgf.uchile.cl/rene/AIMMS20/ and summarized in Table 4 . The flight patterns include porpoising and spiraling between 500 and $4000 \mathrm{ft}$ above the sea surface over the bays of Tongoy/Coquimbo and the bay of Arauco (geographically similar to the CUpEx region but at $37^{\circ} \mathrm{S}$ ), as well as constant 
Table 4. Summary of research flights using the AIMMS-20 mounted in the DGAC Beechcraft King Air BE90. Further details provided online at http://dgf.uchile.cl/rene/AIMMS20/

\begin{tabular}{|c|c|c|c|}
\hline Mission & Date/hours & Sampled region & Low-level wind conditions \\
\hline Met-1 & $\begin{array}{l}23 \text { Dec 2009 } \\
\text { 11:00-15:00 LT }\end{array}$ & $\begin{array}{l}\text { Offshore zonal transect }(\sim 150 \mathrm{~km}) \\
\text { at } 33.5^{\circ} \mathrm{S}\end{array}$ & Weak southerlies along the coast. Coastal jet not present. \\
\hline Met-2 & $\begin{array}{l}\text { 07 Jan 2010 } \\
\text { 11:00-15:00 LT }\end{array}$ & $\begin{array}{l}\text { Offshore zonal transect }(\sim 150 \mathrm{~km}) \\
\text { at } 33.5^{\circ} \mathrm{S}\end{array}$ & Moderate southerlies along the coast. Coastal jet core at $36^{\circ} \mathrm{S}$. \\
\hline Met-3 & $\begin{array}{l}21 \text { Jan } 2010 \\
11: 00-15: 00 \text { LT }\end{array}$ & $\begin{array}{l}\text { Offshore zonal transect }(\sim 150 \mathrm{~km}) \\
\text { at } 33.5^{\circ} \mathrm{S}\end{array}$ & Strong southerlies along the coast. Coastal jet core at $33^{\circ} \mathrm{S}$. \\
\hline Met-4 & $\begin{array}{l}\text { 13 Jul } 2010 \\
11: 00-17: 00 \mathrm{LT}\end{array}$ & $\begin{array}{l}\text { Alongshore transect } 32-30^{\circ} \mathrm{S} \\
\text { Bays of Tongoy and Coquimbo }\end{array}$ & Strong southerlies along the coast. Offshore coastal jet at $30^{\circ} \mathrm{S}$. \\
\hline Met-5 & $\begin{array}{l}27 \text { Dec } 2010 \\
11: 00-17: 00 \text { LT }\end{array}$ & $\begin{array}{l}\text { Alongshore transect } 33-36^{\circ} \mathrm{S} \\
\text { Bay of Arauco }\left(37^{\circ} \mathrm{S}\right)\end{array}$ & Moderate southerlies along the coast. Near coastal jet off point Lavapie. \\
\hline Met-6 & $\begin{array}{l}4 \text { Jan } 2011 \\
11: 00-17: 00 \mathrm{LT}\end{array}$ & $\begin{array}{l}\text { Alongshore transect } 32-30^{\circ} \mathrm{S} \\
\text { Bays of Tongoy and Coquimbo }\end{array}$ & Strong southerlies along the coast. Near coastal jet off point Lengua de Vaca \\
\hline Met-7 & $\begin{array}{l}28 \text { Jan } 2011 \\
11: 00-17: 00 \text { LT }\end{array}$ & $\begin{array}{l}\text { Alongshore transect } 33-36^{\circ} \mathrm{S} \\
\text { Bay of Arauco }\left(37^{\circ} \mathrm{S}\right)\end{array}$ & Strong southerlies near-coastal jet off point Lavapie \\
\hline
\end{tabular}

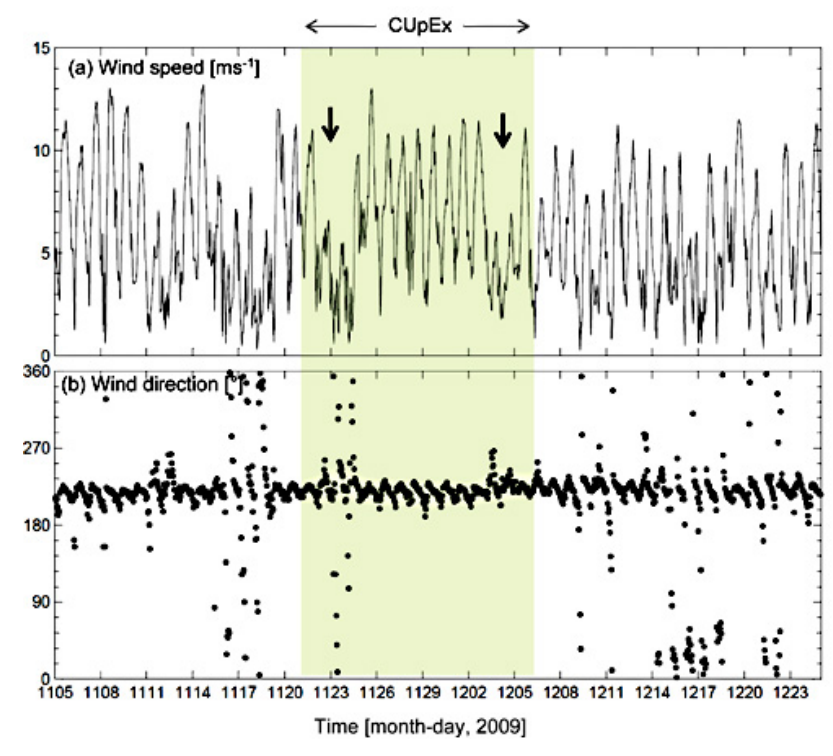

Fig. 4. Half-hourly records of wind speed (upper panel) and wind direction (bottom panel) panel at point Lengua de Vaca during November/December 2009. Central, colored area indicates CUpEx period. The two vertical arrows indicate southerlies relaxation events.

level alongshore transects off the coast at $33.5^{\circ} \mathrm{S}$ under a variety of wind conditions (Table 4 ).

\section{Synoptic variability}

Although the CUpEx area is located in a subtropical region with relatively stable climate, the atmospheric circulation does exhibit synoptic-scale variability with significant impacts on the upper ocean (Garreaud et al., 2002; Narváez et al., 2006). Figure 4 shows the $3-\mathrm{m}$ wind speed and direc-

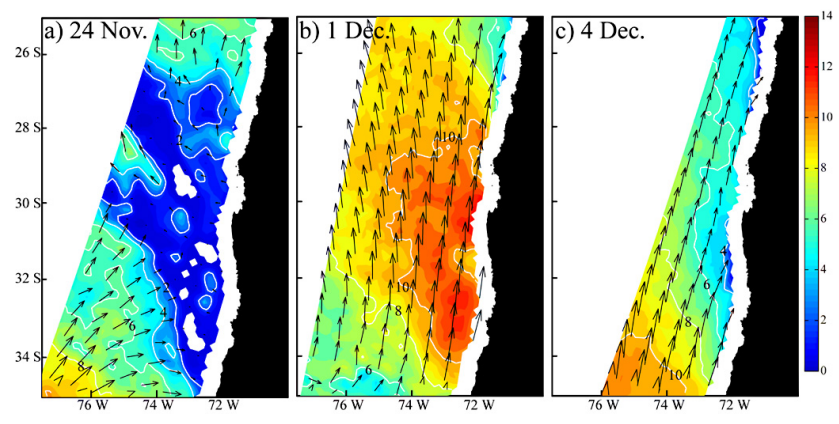

Fig. 5. ASCAT-derived surface wind speed (colours, common scale at right in $\mathrm{ms}^{-1}$ ) and wind vectors (arrows) at 15:00 UTC (11:00 LT) of (a) 24 November, (b) 1 December and (c) 4 December 2009 .

tion at point LdV during November-December 2009, highlighting the CUpEx period. Strong afternoon SW winds $\left(>10 \mathrm{~m} \mathrm{~s}^{-1}\right)$ are prevalent in these months, interrupted by 2 3 days of relaxed flow with nearly weekly periodicity (Garreaud and Muñoz, 2005). During CUpEx we experienced an 8-day long high-wind period bounded by two low-wind events: one at the beginning of the campaign (22-23 November) and one at its end (3-4 December). The relaxation of the southerly winds was evident in the rest of the coastal stations (except those in the sheltered bay where the wind is typically low) as well as over a wider area off the subtropical coast $\left(28-32^{\circ} \mathrm{S}\right)$ as revealed by ASCAT-derived $10-\mathrm{m}$ winds (Fig. 5). Both events were associated with a weakening (and even reversal) of the meridional sea level pressure (SLP) gradient force along the subtropical coast, that in normal conditions points northward and is balanced by friction within the AMBL (Fig. 6a; Muñoz and Garreaud, 2005). The first event was strong and caused by the passage of a surface low/upper trough in southern Chile (Fig. 6c), leading to brief periods of weak northerly winds at Point LdV. In the second event, the 

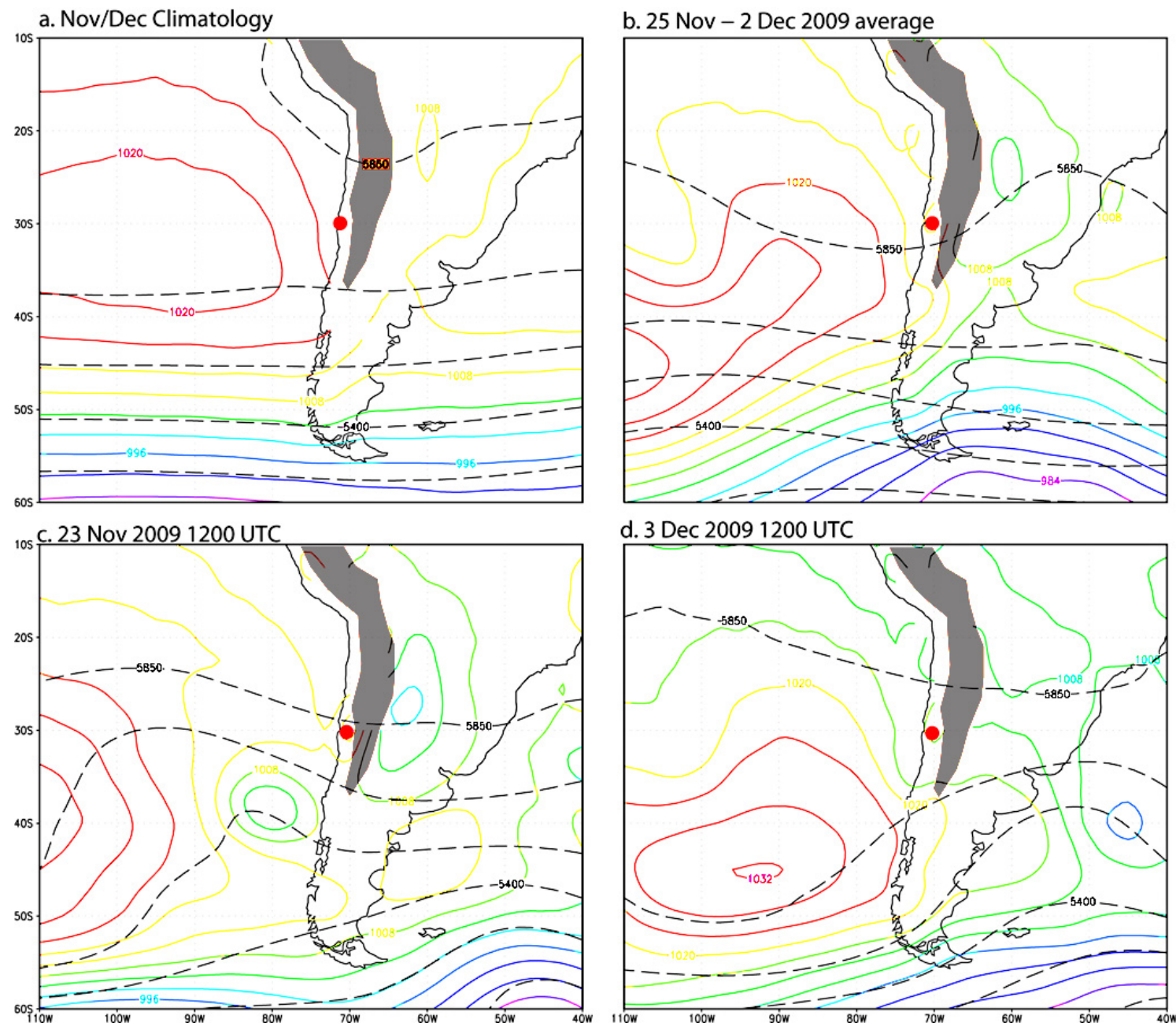

Fig. 6. Daily mean sea level pressure (solid, color lines every $4 \mathrm{hPa}$ ) and $500 \mathrm{hPa}$ geopotential height (dashed, black lines every $150 \mathrm{~m}$ ) for selected dates and periods. Light brown area indicates terrain elevation in excess of $2000 \mathrm{~m}$ a.s.l. Red dot indicates Tongoy area. (a) November-December long-term mean. (b) 25 November-2 December 2009 average (high-wind CUpEx period). (c) 23 November 2009 (first southerly wind relaxation during CUpEx, including brief periods of northerlies). (d) 3 December 2009 (second southerly wind relaxation during CUpEx). Data source: NCEP-NCAR reanalysis.

SEP anticyclone was very strong but located abnormally to the south (Fig. 6d) leading to strong southerly winds around $40^{\circ} \mathrm{S}$ but weak southerlies in the CUpEx area. The stable, strong wind period between 25 November and 3 December featured a moderate meridional SLP gradient at subtropical latitudes and a ridge aloft (Fig. 6b).

The broad impact of the southerly wind variations upon SST is illustrated in Fig. 7 by SSMI-derived SST fields averaged during the two low-wind periods and the high-wind period in between. In the latter period, there is a coastal SST minimum rooted just south of Point LdV and extending northward to the west of the Tongoy/Coquimbo bay. As expected, the relaxation of the southerly wind during CUpEx resulted in a SST warming $\left(>0.5^{\circ} \mathrm{C}\right)$ in a coastal swath about $50 \mathrm{~km}$ wide between $31^{\circ}$ and $29^{\circ} \mathrm{S}$. The area and magnitude of this warming is similar to a cooling event in October 2000 documented by Renault et al. (2009) relying on satellite data as well. In-situ data taken during CUpEx allows a more detailed description of the upper-ocean response to varying surface winds, as illustrated by several time series of SST in Fig. 8. At Talcaruca (south of Point LdV, Fig. 2) the first southerly wind relaxation (with episodic northerlies) brought a gradual increase of SST $\left(\sim 1.4^{\circ} \mathrm{C}\right.$ in two days) until the end of the low-wind period, followed by a more or less symmetric SST decrease as the southerly winds strengthened. In contrast, the sea surface warming at Chañaral de Aceituno (ChA), in the northern end of the embayment (Fig. 2), was similar in magnitude but concentrated in less than $12 \mathrm{~h}$ at the end of the low-wind period; the subsequent cooling was much more gradual. The 5-m deep sea temperature at the Tongoy bay buoy experienced a slight warming during the wind relaxation, followed by a dramatic cooling $\left(4^{\circ} \mathrm{C}\right.$ in $24 \mathrm{~h}$ 


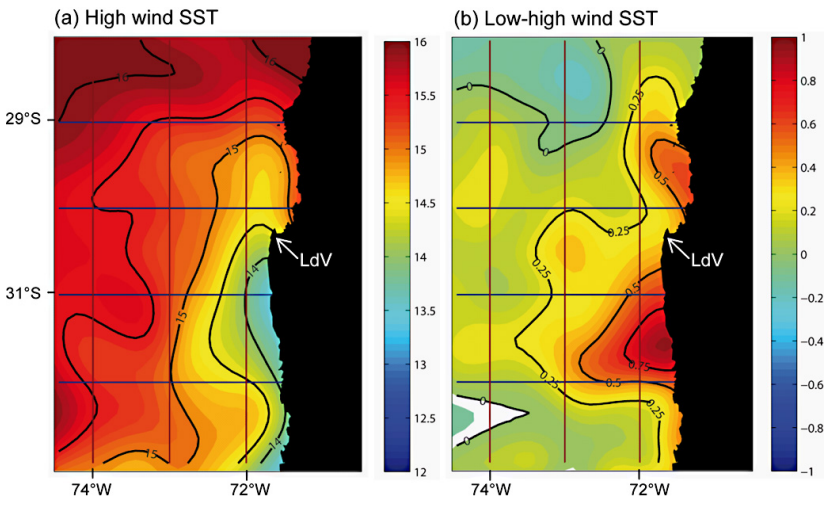

Fig. 7. Sea surface temperature (SST) derived from the Special Sensor Microwave/Imager (SSM/I; see details in Wentz 1997). (a) Average of SST during the high-wind period (24 November to 2 December 2009). Contours every $0.5^{\circ} \mathrm{C}$. (b) SST difference between low-wind days (22 November, 23 November, 3 December, 4 December) minus high-wind period. Contours every $0.25^{\circ} \mathrm{C}$ Arrowhead indicates location of point Lengua de Vaca.

and $2{ }^{\circ} \mathrm{C}$ in $1 \mathrm{~h}$ ) the first day of strong winds. The low-wind period at the end of CUpEx produced little, if any, SST response in Talcaruca and Chañaral de Aceituno, but a strong signal in the bay of Tongoy (Fig. 8). The diverse evolution of SST in space and among events reveals a complex response of the coastal upwelling and downwelling, as well as horizontal heat transport, to the varying winds which calls for high-resolution ocean modelling for a complete understanding (as in Ramp et al., 2005). It also requires further study of ocean variability and its relationship to changes in oceanic and atmospheric regimes during the spring transition (e.g., Ramp and Bahr, 2008) around the CUpEx period. We also note that large sea surface warming (downwelling) during relaxed wind events dominate the SST high-frequency variability during the upwelling-favourable, cold-SST regime in austral spring and summer (Fig. 9, upper panels). The warm events also play a key role in the ocean biology as the onshore advection also brings high concentrations of nutrients (e.g., Narváez et al., 2006) and often lead to phytoplankton blooms (e.g., Rutllant and Montecino, 2002).

The time-depth section of ocean temperatures recorded at the coastal mooring off Talcaruca during CUpEx is shown in the lower panel of Fig. 9. At the beginning of the campaign, still under strong southerlies, the temperature profile is quite uniform throughout the column except for a weak increase $\left(\Delta T \sim 0.2^{\circ} \mathrm{C}\right)$ in the upper $20 \mathrm{~m}$. The first relaxation of the southerly winds produced a warming of $\sim 1.5^{\circ} \mathrm{C}$ in the upper $25 \mathrm{~m}$ (similar to the surface warming) and $\sim 0.5^{\circ} \mathrm{C}$ below $80 \mathrm{~m}$, thus increasing the thermal stratification. Most of the upper-ocean warming occurred sharply about $12 \mathrm{~h}$ after the surface wind relaxed and further continued during the low-wind period. The subsequent cooling - after the southerly winds picked up - was much more gradual and in-

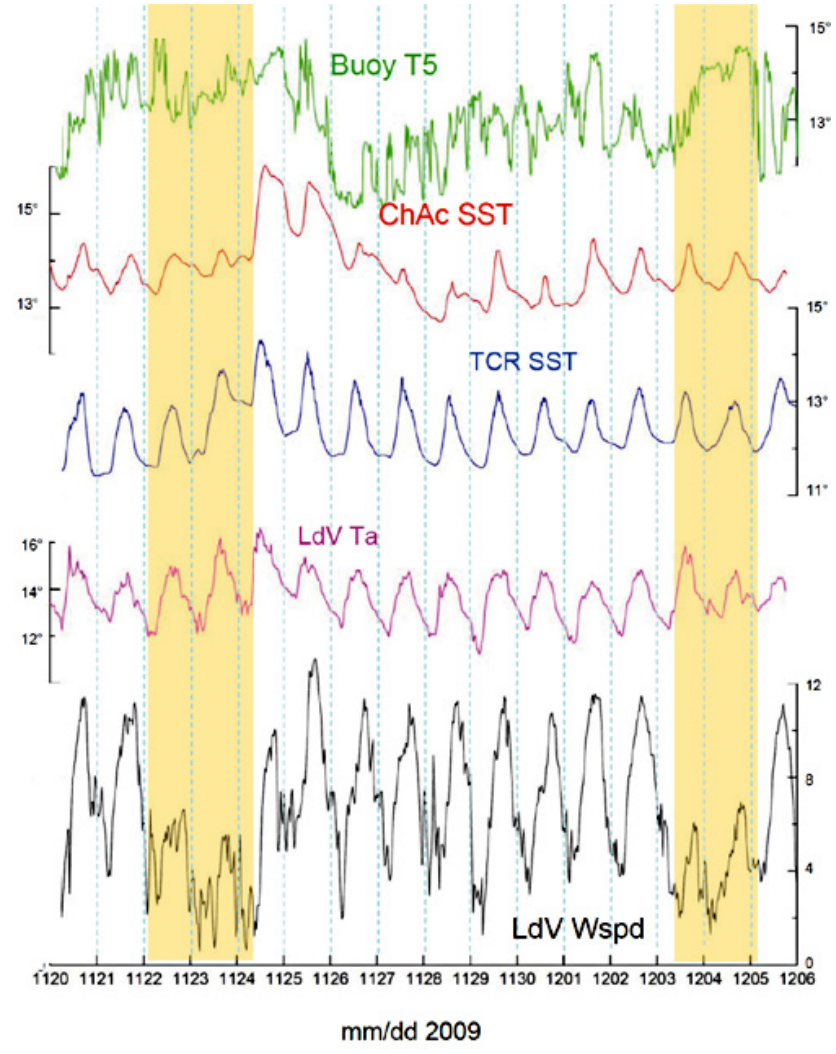

Fig. 8. Times series of selected coastal variables during CUpEx (30-min averages). From bottom to top the variable are: $3.8-\mathrm{m}$ wind speed (black line) and 2-m air temperature (magenta line) at point Lengua de Vaca, shore SST at Talcaruca (TCR, blue line) and Chañaral de Aceituno (ChAc, red line), and 5-m deep sea temperature at the Tongoy bay buoy (green line). The yellow-shaded rectangles indicate the low-wind periods during CUpEx.

terrupted by a warming at the end of November not related to wind changes. The column-deep warmer conditions suggest a rapid seasonal transition and set the stage for a stronger warming near the surface during the next wind relaxation (Fig. 9). Notably, as documented later, the southerly wind relaxations are often accompanied by an increase in low level clouds (significantly reducing the incoming solar radiation) indicative of the major role of onshore horizontal advection during these ocean warming events.

Synoptic changes during CUpEx were not restricted to the surface wind but also affected the low-level atmospheric structure as illustrated by the sequence of AM soundings at Talcaruca (Fig. 10a). During the high-wind period the AMBL depth varied between $400-600 \mathrm{~m}$, capped by a strong temperature inversion (TI). Compared to the average spring/summer conditions elsewhere along the coast (Rahn and Garreaud, 2010b), the "mean" (high-wind period) AMBL at $30^{\circ} \mathrm{S}$ is half as deep as in northern Chile (Antofagasta, $23^{\circ} \mathrm{S}$ ) and slightly deeper than at central Chile (Santo Domingo, $33^{\circ} \mathrm{S}$ ), although in this last location the AMBL 


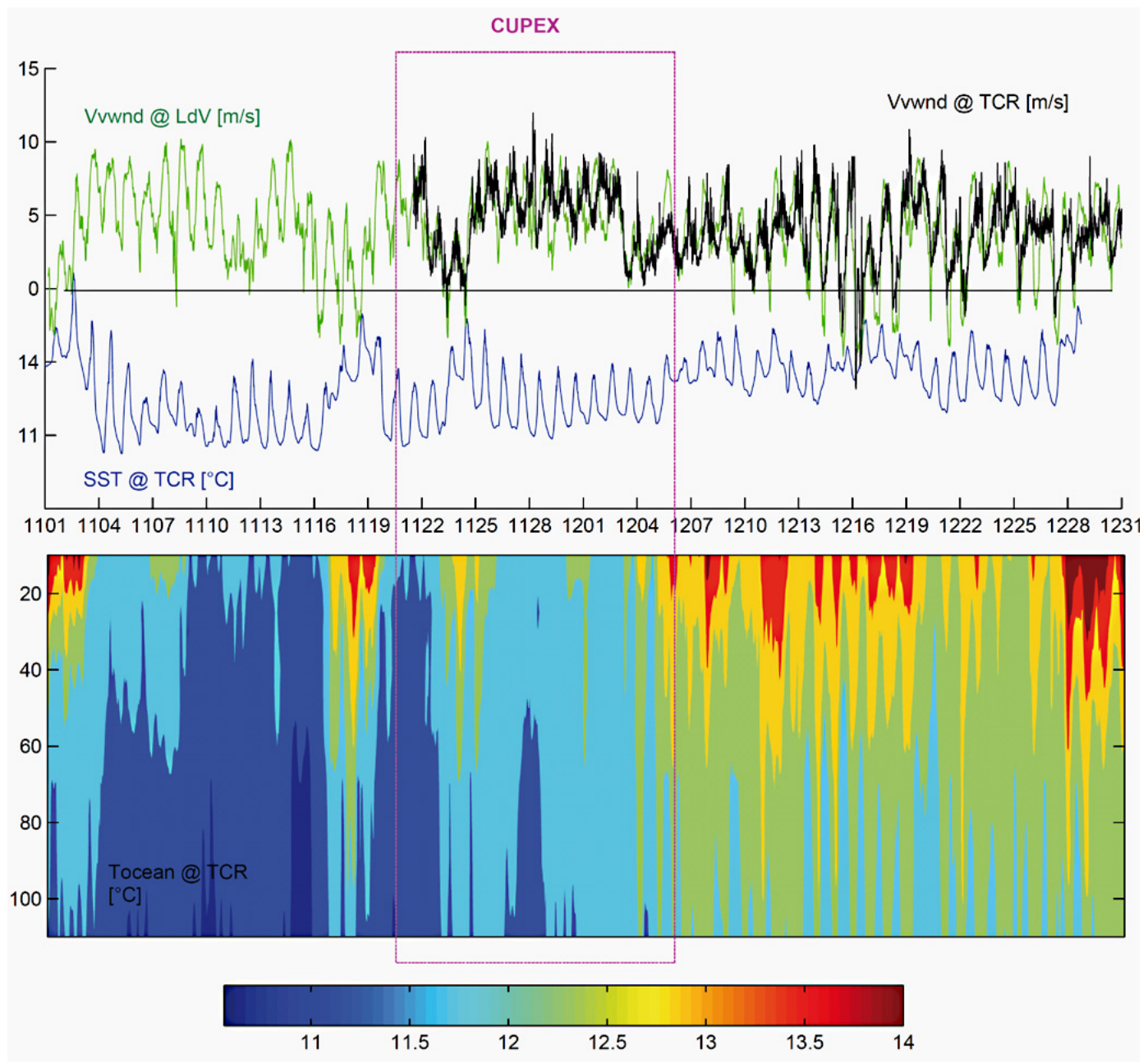

Fig. 9. Lower panel: time-depth section of ocean temperatures (in ${ }^{\circ} \mathrm{C}$, scale at the bottom; time is indicated in mmdd format in the upper panel) recorded by the mooring $2.2 \mathrm{~km}$ off Talcaruca during November-December 2009. The CUpEx period is indicated by the magenta rectangle. The temperature is measured every hour at 5, 10, 15, 20, 25, 30, 40, 50, 70, 90 and $110 \mathrm{~m}$. Upper panel: time series of meriodional wind at point Lengua de Vaca (green line) and Talcaruca (black line), and shore SST at Talcaruca (blue line).

is defined only $70 \%$ of the time. The low-level TI weakened and eventually disappeared during 24 and 25 November in connection with ascending motion over the CUpEx area ahead of an upper-level trough (Figs. $6 \mathrm{~b}$ and 10). The AMBL/TI reformed by 26 November as the mid-level subsidence reappeared (vertical velocity from NCEP-NCAR reanalysis), more than a day after the strengthening of the surface southerlies. The TI was not eroded during the second low-wind event (consistent with the persistence of the midlevel subsidence, Fig. 10) but its base experienced a significant lift from $\sim 30 \mathrm{~m}$ on 2 December to $\sim 1000 \mathrm{~m}$ on 4 December.

The deepening of the AMBL at the end of the campaign was associated with a southward expansion of a wedge of coastal stratus, which had remained to the north of the CU$\mathrm{pEx}$ area during the previous days (Fig. 11). During the dawn and morning of 3 and 4 December, the ceilometer- derived cloud base height was $\sim 200-300 \mathrm{~m}$ (not shown), so the cloud layer encompassed most of this deep AMBL. The thick low clouds reduced the insolation to half of the value during clear-sky days $(\sim 13.2 \mathrm{MJm}-2)$. Such a transition between low/high AMBL, clear/cloudy skies and strong/weak southerly winds has been previously identified at the demise stage of a coastal low in central Chile (e.g., Garreaud et al., 2002), but the wealth of observations during CUpEx (particularly the sounding data) will allow a more thoughtful analysis of these changes. Further, the full sequence of satellite images of this poleward expansion of the stratus clouds resembles coastally trapped phenomena in western North America (e.g., Nuss et al., 2000; Nuss, 2007), which has been diversely interpreted as density currents, Kelvin waves or purely synoptically-driven events. Notably, the southward expansion of the cloud wedge during CUpEx occurred against weak but persistent southerly winds within and above 


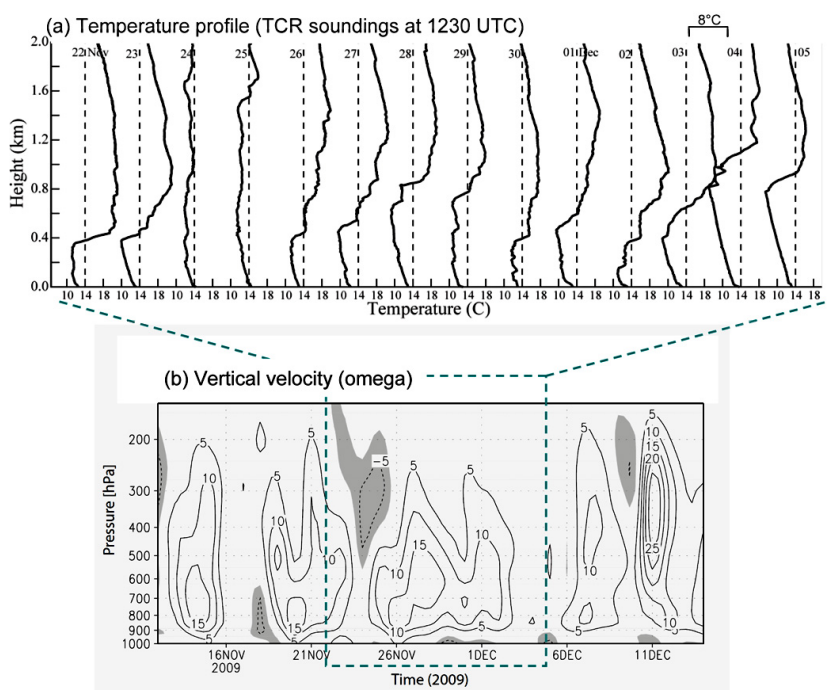

Fig. 10. (a) Vertical profiles of air temperature from the 12:30 UTC (morning) soundings at Talcaruca for each day during CUpEx (dates at the top). The horizontal (temperature) scale is identical for each sounding and the vertical dashed line is the reference $14{ }^{\circ} \mathrm{C}$ isotherm. (b) Vertical velocity $(\omega \cdot 100$, contoured every $0.05 \mathrm{hPa} \mathrm{s}^{-1}$, shaded area indicates ascending motion) at $30^{\circ} \mathrm{S}$, $73^{\circ} \mathrm{W}$ during November-December 2009. The CUpEx period is indicated by the green box. Data source: NCEP-NCAR reanalysis.

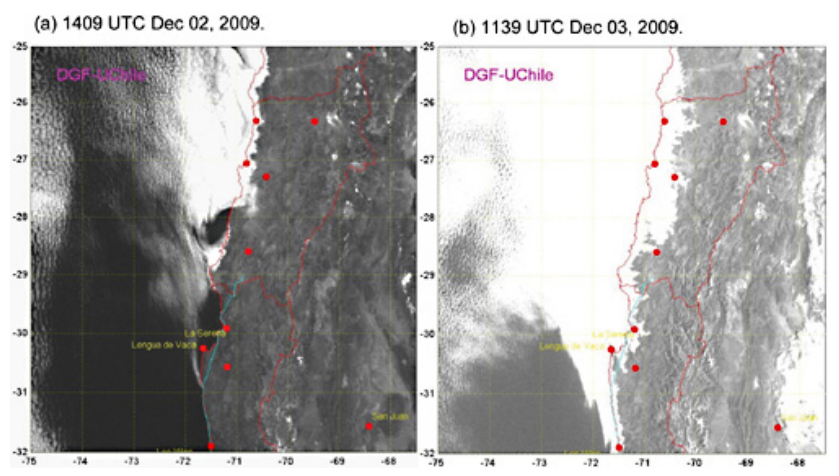

Fig. 11. GOES-13 visible images over the CUpEx area for (a) 14:09 UTC 2 December 2009, and (b) 11:39 UTC 3 December 2009 .

the coastal AMBL, ruling out a density current as a mechanism for the AMBL recovery.

\section{Mean diurnal cycles}

Having described the synoptic changes during CUpEx we now turn our attention to the mean diurnal cycle of selected meteorological and oceanographic fields. Here we take advantage of the stable, high-wind conditions that prevailed from 25 November to 2 December (Fig. 4). During this period, the diurnal cycle of the surface wind at Point LdV not only repeated very regularly but it was also close to the longterm mean diurnal cycle for late spring computed on the basis of $9 \mathrm{yr}$ of records, lending some climatological credentials to the results analyzed here.

Figure 12 shows the station-based 3-m winds averaged during the strong-wind period (or November-December for non-CUpEx data) every $6 \mathrm{~h}$. Recall that southerly flow dominates off the coast of north-central Chile, with a relatively modest diurnal cycle (Muñoz, 2008). The inland stations and those along the bay of Tongoy/Coquimbo show a marked diurnal cycle in speed and direction associated with the development of a daytime sea-land breeze. The maximum speed occurs during the afternoon, with directions pointing inland, while nighttime and early morning winds are seaward and low. A dramatic case occurs at Tongoy (coastal station and buoy) where the morning-to-afternoon surface wind blows from the north. As shown later, the northerly flow at Tongoy is restricted to the first $200 \mathrm{~m}$ capped by southerlies aloft. The shallow sea breeze (northerly flow detected at Tongoy) is able to penetrate about $50 \mathrm{~km}$ inland over the dry plains south of the bay (as detected in station Quebrada Seca), but it is rapidly substituted by wind from the south around midday. Southerly wind is prevalent throughout the day at coastal stations that are better exposed (outside of the bay) to the offshore and regional southerlies. Nevertheless, the afternoon development of an onshore flow component is also evident at point LdV and other coastal stations where the highest winds around 18:00 LT are from the SW (Fig. 12b), followed by light winds during nighttime (the absence of onshore flow at Talcaruca is likely due to the presence of a coastal cliff immediately to the east). In contrast, the nearly invariable southerly wind direction $\left(180^{\circ} \pm 10^{\circ}\right)$ at Islote Pajaros, only $23 \mathrm{~km}$ off the coast, suggests a very rapid spatial decay of the afternoon onshore flow within the embayment area.

During the afternoon, the wind speed increases from Talcaruca to Point LdV (SW in excess of $10 \mathrm{~m} \mathrm{~s}^{-1}$ ) and decays slightly at Islote Pajaros (Fig. 12c). This alongshore variability suggests the existence of a near-shore coastal jet off the bay of Tongoy/Coquimbo, extending a few tens of $\mathrm{km}$ to the north of point LdV. Such a feature is consistent with the maximum wind speed during afternoon just to the north-west of point LdV evident in the QuikScat climatology (Fig. 3b) and it is also resolved by high resolution (3 km) atmospheric modelling (Rahn et al., 2010). A very vivid detection of the near-coastal jet immediately north of point $\mathrm{LdV}$ was obtained by a research flight over the bay of Tongoy in 11 January 2011 (Met-6, Table 4). As illustrated in Fig. 13, the low-level wind speed increased from about $10 \mathrm{~m} \mathrm{~s}^{-1}$ in the sheltered bay to $25 \mathrm{~m} \mathrm{~s}^{-1}$ just north of point $\mathrm{LdV}$ and decreased gradually offshore down to $15 \mathrm{~m} \mathrm{~s}^{-1}$ over open ocean. The localized wind speed maximum is due both to strong southerlies and westerly flow. We will offer a possible explanation on the origin of this jet after describing the distinctive diurnal cycle of the lower troposphere temperature over the bay and offshore. This strong, diurnally-varying 
(a) $06 \mathrm{LT}$

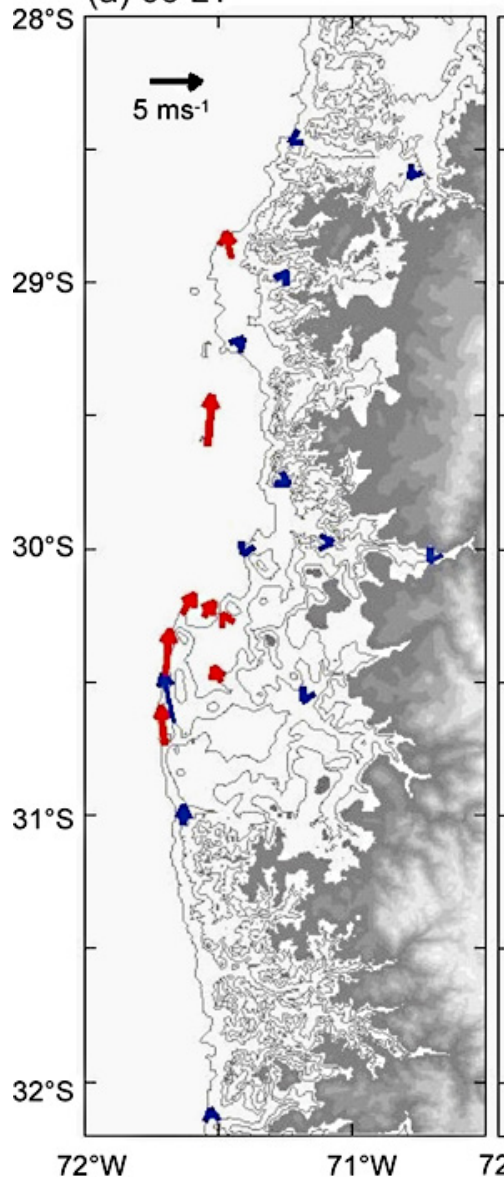

(b) $12 \mathrm{LT}$

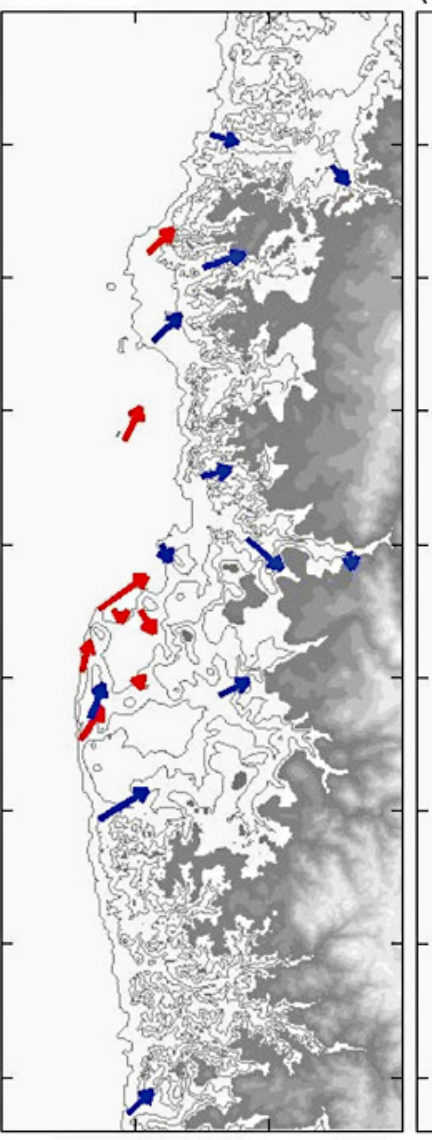

(c) $18 \mathrm{LT}$

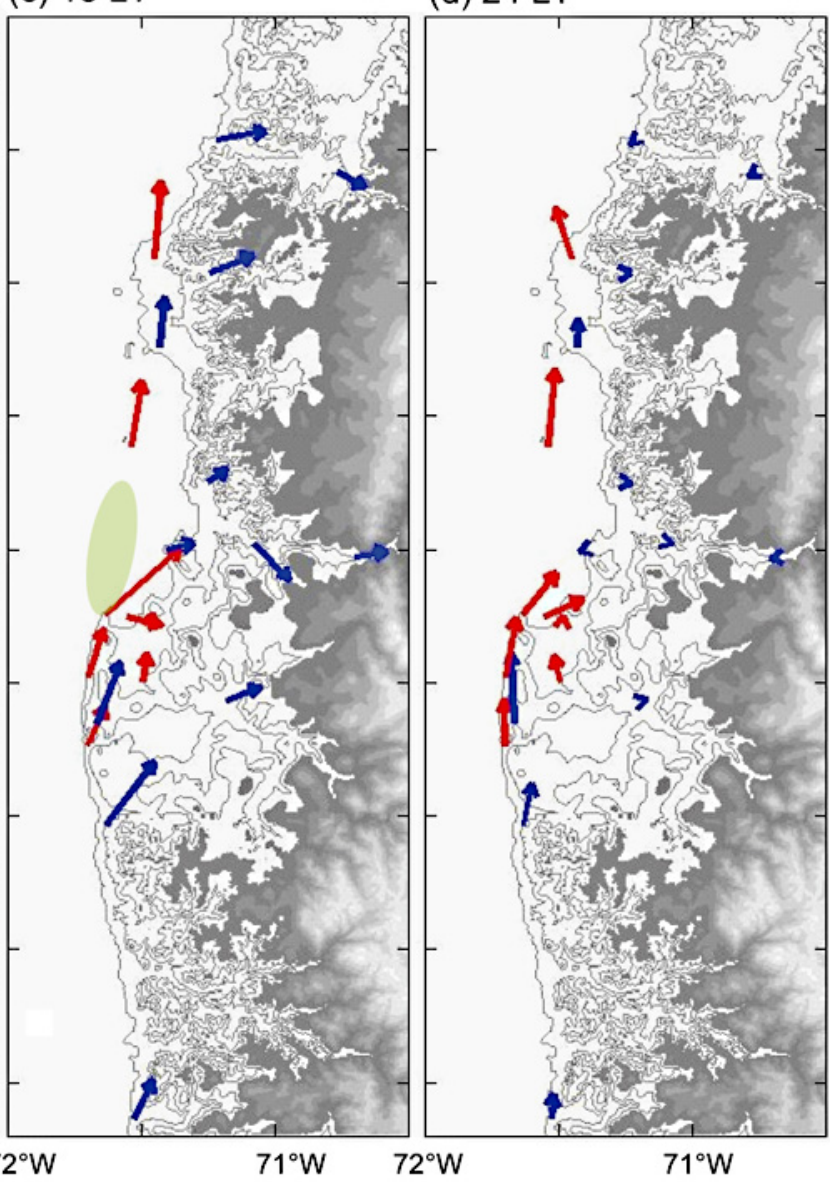

Fig. 12. Mean diurnal cycle of the $10-\mathrm{m}$ winds over the CUpEx area, illustrated by the average wind vectors every 6-h (local time atop of each panel). Red arrows are average winds during CUpEx. Blue arrows are average winds for November/December obtained from different datasets (obtained from Muñoz et al., 2003). The green area at 18:00 LT (panel c) indicates the core (wind speed $\geq 15 \mathrm{~m} \mathrm{~s}^{-1}$ ) of the near-shore coastal jet detected in airborne mission 6 (Table 4, see Fig. 13) and obtained from a WRF numerical simulation ( $3 \mathrm{~km}$ horizontal resolution) of the CUpEx period described in Rahn et al., 2010. Topographic contours every $250 \mathrm{~m}$, shaded above $1000 \mathrm{~m}$ a.s.l.

near-coastal atmospheric jet could be a major driver of the oceanic circulation in the CUpEx area, especially in the bay of Tongoy/Coquimbo. The afternoon jet fosters strong alongshore wind stress and cyclonic wind stress curl onshore of the jet axis. The diurnal pulse given by the wind can also excite inertial oscillations in the ocean with a period that equals 24$\mathrm{h}$ at $30^{\circ} \mathrm{S}$. A glimpse of this effect is shown in Fig. 14 by the time series of the radar-derived radial sea-surface velocity for a point in the center of the bay of Tongoy $\left(30^{\circ} \mathrm{S}, 71.65^{\circ} \mathrm{W}\right)$. There is a marked diurnal cycle in the currents with weak N-NW flow (toward Tongoy) during the morning, and S-SW flow (away from Tongoy) the rest of the day, peaking at midnight. Thus, the diurnal cycle of the surface currents lags its surface wind counterpart by 3-6h.

Diurnal changes in the AMBL/inversion structure are depicted in Fig. 15 by the morning (08:30 LT) and afternoon (17:30 LT) vertical profiles of air temperature and meridional wind at Tongoy and Talcaruca averaged during the highwind period. Both morning soundings exhibit a well mixed $\sim 450 \mathrm{~m}$ deep AMBL, capped by the TI up to about $1300 \mathrm{~m}$. Even at this time of the day, the AMBL is slightly cooler at Talcaruca than at Tongoy, likely because of nearby SST differences. As the day progresses, both profiles show a warming of the AMBL: relatively modest in Talcaruca $\left(2{ }^{\circ} \mathrm{C}\right)$ and very marked in Tongoy $\left(7^{\circ} \mathrm{C}\right)$. The afternoon AMBL at Talcaruca remains about $400 \mathrm{~m}$ deep, but a nearly isothermal layer develops within the initial TI at about $700 \mathrm{~m}$ (Fig. 14), about the same height of the nearby coastal topography and collocated with a layer of light easterly (offshore) flow (not shown). Also notable in Talcaruca is the presence of two southerly wind maxima (Fig. 12), the strongest in the lowest $200 \mathrm{~m}$ (stronger during afternoon) and a secondary one within the temperature inversion aloft. Such conspicuous "double-inversion/double-jet" structure appears in each individual sounding during the central-CUpEx period, as well as in subsequent airborne coastal transects, and deserves further study to elucidate its origin. 


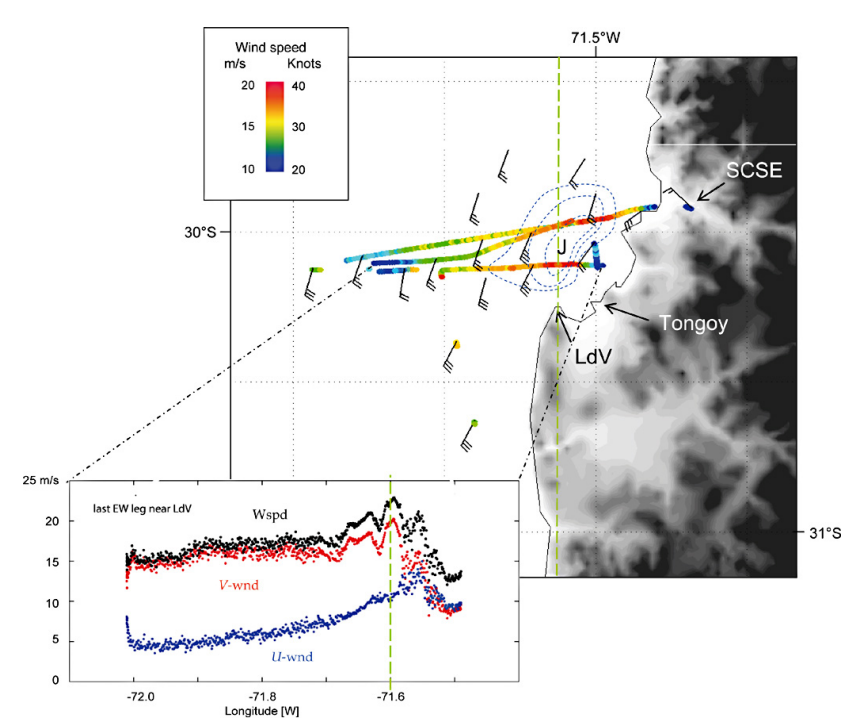

Fig. 13. Central map: colour-coded wind speed measured by the AIMMS-20 onboard of the BE90 during a portion of the research flight Met-6 (11 January 2011). Between 14:00-15:00 LT the BE90 flew over the bay of Tongoy between 170 and 220 ma.s.l. A few wind barbs are included to illustrate the general SW flow in this region. The near coastal jet immediately to the north of point Lengua de Vaca $(\mathrm{LdV})$ is evident (marked with a $\mathrm{J}$ in the hand made analysis). The lower inset shows the wind speed, zonal and meridional components at about $200 \mathrm{~m}$ a.s. 1 as a function of the longitude in a near zonal transect at $30.2^{\circ} \mathrm{S}$. The dashed green line indicates the axis of the coastline south of LdV.

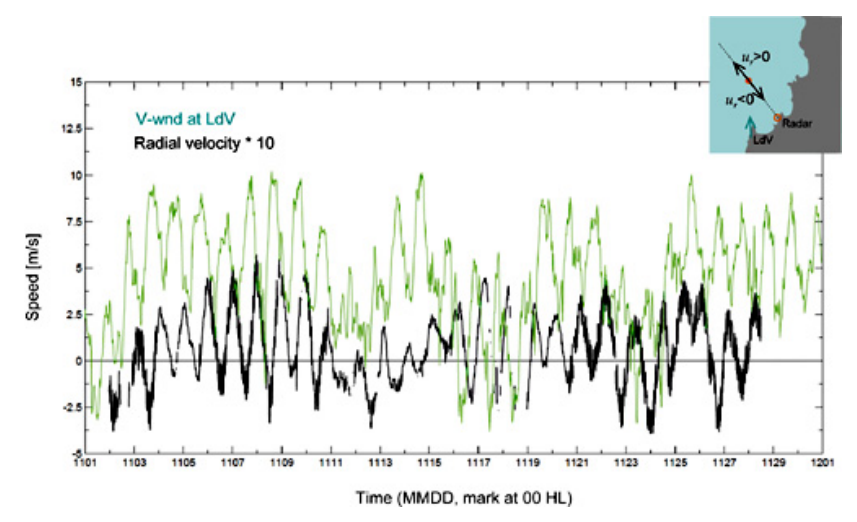

Fig. 14. Radial surface current at $30^{\circ} \mathrm{S}, 71.5^{\circ} \mathrm{W}$ (black line) measured from the Tongoy HF Radar. Positive (negative) values away from (toward) the radar (see inset). Also shown is the meridional wind speed at point Lengua de Vaca (green line).

The near surface air over Tongoy warms $\sim 7^{\circ} \mathrm{C}$ from morning to afternoon and creates a super-adiabatic layer about $50 \mathrm{~m}$ deep (note that Tongoy soundings are launched from a land site about $100 \mathrm{~m}$ from the shore). Such local surface heating, if acting alone, would deepen the mixed layer (with $\Gamma \sim 10^{\circ} \mathrm{km}^{-1}$ ) up to about $600 \mathrm{~m}$. Instead, the afternoon sounding at Tongoy exhibits a nearly isothermal
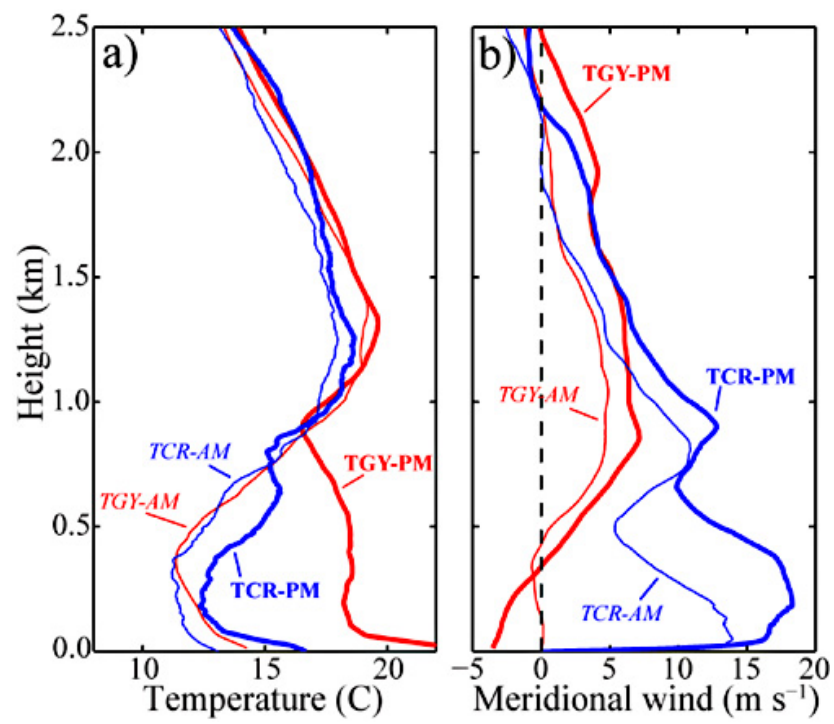

Fig. 15. Morning (08:30 LT, thin lines) and afternoon (17:30 LT, thick lines) mean profiles of (a) air temperature and (b) meridional wind at Talcaruca (blue lines) and Tongoy (red lines). The averages were calculated with the soundings during the CUpEx high-wind period (25 November-2 December 2009).

layer up to $600 \mathrm{~m}$ capped by less stable layer (nearly well mixed) that intercepts the TI at about $950 \mathrm{~m}$ (Fig. 15). We hypothesize that such multi-layer structure and the afternoon warming of the lower troposphere, in excess of purely local heating, is accounted by vertically varying meridional advection. With the exception of the shallow surface layer with northerly flow (daytime sea breeze), the afternoon AMBL/TI over Tongoy is dominated by southerly winds (Fig. 15; zonal component $<1 \mathrm{~m} \mathrm{~s}^{-1}$ ). Considering a uniform southerly wind of $5 \mathrm{~m} \mathrm{~s}^{-1}$, the air parcels arriving at Tongoy in lateafternoon have traveled about $80 \mathrm{~km}$ during the last $6 \mathrm{~h}$, being subject to strong diabatic heating over the dry plains that extends to the south of the bay and separated from the ocean by the near-shore coastal range (Fig. 2) of about $500 \mathrm{~m}$ height. Further analysis of modelling and observations is needed to validate this hypothesis.

Regardless of the origin of the low-level warming over Tongoy, its magnitude is much larger than that over Talcaruca, largely explaining a $3 \mathrm{hPa}$ surface pressure difference between these two points during the afternoon. Daytime airborne observations (missions 4 and 6) reveal that such station-to-station difference during the afternoon is spatially coherent between the southern part of the Tongoy bay and the open ocean to the west of $70.6^{\circ} \mathrm{W}$ (not shown). The thermally-driven SLP gradient seems to act as the main driver of the near-coastal jet near LdV described before, by inducing strong isallobaric acceleration after midday (Rahn et al., 2010). The warming over Tongoy also reduces the low-level relative humidity from $80 \%$ in the morning to less than $50 \%$ in the afternoon, contributing to the recurrent 
daytime breakup of the stratus cloud deck over the Tongoy bay (Fig. 3c). We note, however, that clear-skies often prevail during nighttime over Tongoy, as revealed by the laser ceilometer, in an otherwise cloudy environment (not shown). The latter suggests a nocturnal, local depression of the AMBL that may arise from an expansion fan (see Koraèin et al., 2004 for a review of this feature) as the coastal southerly winds turn eastward into the bay of Tongoy just north of point LdV.

\section{Conclusions}

The Chilean Upwelling Experiment (CUpEx) was a regional component of VOCALS designed to address the loweratmosphere and upper-ocean dynamics that characterize the near-shore $(0-100 \mathrm{~km})$ region off north-central Chile. This portion of the subtropical coast of South America marks the transition between an extremely stable and dry region to the north and a more synoptically active region to the south. The CUpEx intensive observation period took place in late austral spring, between the last week of November and the first week of December 2009. We were fortunate that the brief CUpEx period included an 8-day sequence with strong, upwellingfavorable southerlies and very stable conditions - suitable to characterize the mean diurnal cycles - bounded by two relaxed-wind events - suitable to describe synoptic changes in the ocean and atmosphere.

The observations were centered around $30^{\circ} \mathrm{S}$ (a generally data-void sector) in a coastal area that features a straight south-north coastline along $\sim 70.6^{\circ} \mathrm{W}$ (ending at Point Lengua de Vaca) followed by a wide, northwest-facing embayment (including the Tongoy and Coquimbo bays). Such configuration replicates elsewhere along the Chilean (and Peruvian) coast. CUpEx measurements included two radiosonde stations, several coastal automatic weather stations and SST loggers, a laser-ceilometer, HF sea radars, and an instrumented bay buoy and two coastal moorings (ADCP and chain of thermometers). Six research flights encompassing a wider area off central Chile have been conducted in the subsequent months to sample the offshore AMBL circulation and thermodynamic structure.

In addition to presenting CUpEx goals, strategy and platforms, this work highlights selected observational results. This coastal region exhibits the typical development of an afternoon sea-land breeze, although relatively shallow and rapidly decaying offshore where the southerly winds have little diurnal change. A distinctive "mean" feature of this region is the low-level temperature difference between the open ocean (sampled at Talcaruca) and the southern part of the bay (sampled at Tongoy) that develops during the day. The first kilometer over Tongoy not only is $\sim 5^{\circ} \mathrm{C}$ warmer than over Talcaruca (resulting in a $>3 \mathrm{hPa}$ SLP difference between these two locations), but exhibits a nearly isothermal structure instead of well-mixed boundary layer. The pronounced daytime low-level warming over Tongoy (along with a tendency for clear skies) is likely caused by advection of continental air from the dry lands just to the south of the bay. More importantly, the resulting marked baroclinicity during afternoon drives an intense, near-coastal jet just north of point $\mathrm{LdV}$, stirring the ocean circulation of the bay and adjacent open ocean.

The two relaxed-wind events -including brief periods of northerly flow in the first case during CUpEx- were synoptically driven and produced a rapid (within a day), sizeable $\left(0.5-1{ }^{\circ} \mathrm{C}\right)$ warming of the ocean down to $\sim 100 \mathrm{~m}$ off Talcaruca. Likewise, the ocean cooled rapidly once the southerlies strengthened, reaching a cold, steady condition after 23 days. In contrast to the rather gradual variability in Talcaruca, the ocean temperature changes within the embayment are step while near shore SST records in the northernmost part of the bay exhibit a delayed (if any) response to wind changes. We also note that relaxed-wind events are often accompanied by a deepening of the AMBL fostering cloudy conditions that reduce the insolation by a factor of 2 . The latter emphasizes the role of onshore warm advection in producing the SST warming during relaxed-wind events.

The observational results obtained during CUpEx are now being examined in detail, along with a handful of longerperiod records and high-resolution numerical simulations of the atmosphere and ocean. We hope this new information will improve our understanding of the complex interactions among the atmosphere, land and ocean in the near-shore region of north-central Chile. These issues are relevant for the regional meteorology and on the broader subtropical southeast Pacific climate.

Acknowledgements. VOCALS-CUpEx has been supported by several research grants from CONICYT (Chile). In particular, we acknowledge FONDECYT grants 1090492, 1080606 and 1090791 , as well as FONDEF grant D03I-1104 and INNOVA-Chile 07CN13IXM-150. We also thank the National Weather Service (DMC) and the National Civil Aviation Directorate (DGAC) for their support during the intensive observation period and the research flights. We are grateful of constructive comments by Clive Dorman and one anonymous reviewer.

Edited by: R. Weller

\section{References}

Avissar, R., Holder, H., Abehserra, N., Bolch, M., Canning, P., Magalhaes, J., Walko, R., Novick, K., Katul, G., and Prince, K.: The Duke University Helicopter Observation Platform, B. Am. Meteorol. Soc., 90, 939-954, 2009.

Bakun, A. and Nelson, C. S.: The seasonal cycle of wind-stress curl in subtropical eastern boundary current regions, J. Phys. Oceanogr., 21, 1815-1834, 1991.

Bailey, G. and Chapman, P.: Short-term variability during an anchor station study in the southern Benguela upwelling system: 
Chemical and physical oceanography, Prog. Oceanogr., 28, 937, 1991.

Beardsley, R., Dorman, C., Friehe, C., Rosenfeld, L., and Winant, C.: Local atmospheric forcing during the coastal ocean dynamics experiment 1 . A description of the marine boundary layer and atmospheric conditions over a northern California upwelling region, J. Geophys. Res., 92, 1467-1488, 1987.

Beswick, K. M., Gallagher, M. W., Webb, A. R., Norton, E. G., and Perry, F.: Application of the Aventech AIMMS20AQ airborne probe for turbulence measurements during the Convective Storm Initiation Project, Atmos. Chem. Phys., 8, 5449-5463, doi:10.5194/acp-8-5449-2008, 2008.

Brink, K. H., Allen, J. S., and Smith, R. L.: A Study of LowFrequency Fluctuations Near the Peru Coast, J. Phys. Ocean., 8, 1025-1041, 1978.

Del-Val, E., Armesto, J., Barbosa, O., Christie, D., Gutiérrez, A., Jones, C., Marquet, P., and Weathers, K.: Rain forest islands in the Chilean semiarid region: fog-dependency, ecosystem persistence and tree regeneration, Ecosystems, 9, 598-608, 2006.

Dorman, C. and Winant, C.: Buoy observations of the atmosphere along the west coast of the United States, 1981-1990, J. Geophys. Res., 100, 16029-16044, 1995.

Figueroa, D. and Moffat, C.: On the influence of topography in the induction of coastal upwelling along the Chilean coast, Geophys, Res, Lett., 27, 3905-3908, 2000.

Garreaud, R. and Muñoz, R.: The low-level jet off the west coast of subtropical South America: Structure and variability, Mon. Weather Rev., 133, 2246-2261, 2005.

Garreaud, R., Rutllant, J., and Fuenzalida, H.: Coastal lows along the subtropical west coast of South America: Mean structure and evolution, Mon. Weather Rev., 130, 75-88, 2002.

Garreaud, R., Rutllant, J., Muñoz, R., Rahn, D., Ramos, M., and Figueroa, D.: VOCALS-CUpEx: The Chilean Upwelling Experiment, CLIVAR-Exchanges Newsletter, 15, 5-7, 2010.

Grados, C., Chaigneau, A., Takahashi, K., Dewitte, B., Garreaud, R., and Gallardo, L.: VOCALS-REx Coastal Component, CLIVAR-Exchanges Newsletter, 15, 23-28, 2010.

Gonzalez, C., Rutllant J., and Paolini, P.: Frecuencia y Albedo de Estratocúmulos Costeros entre $24-32^{\circ} \mathrm{S}$. 4to Taller DOCA. Dirección Meteorológica de Chile, Santiago-Chile, 18 y 19 de Octubre de 2007.

Hawkins, J. D. and Stuart, D. W.: Low-Level Atmospheric Changes over Oregon's Coastal Upwelling Region, Mon. Weather Rev., 108, 1029-1040, 1980.

Hormazabal, S., Shaffer, G., and Leth, O.: Coastal transition zone off Chile, J. Geophys. Res., 109, C01021, doi:10.1029/2003JC001956, 2004.

Klein, S. and Hartmann, D.: The seasonal cycle of low stratiform clouds, J. Climate, 6, 1587-1606, 1993.

Koraèin, D., Dorman, C. E., and Dever, E. P.: Coastal Perturbations of Marine-Layer Winds, Wind Stress, and Wind Stress Curl along California and Baja California in June 1999, J. Phys. Oceanogr., 34, 1152-1173, 2004.

Mechoso, C. M. and Wood, R.: An abbreviated history of VOCALS, Clivar Exchanges, 15, 3-5, 2010.

Mittelstaedt, E., Pillsbury, D., and Smith, R.: Flow patterns in the Northwest African upwelling area, Ocean Dynam., 28, 145-167, 1975.
Muñoz, R.: Diurnal cycle of surface winds over the subtropical southeast Pacific, J. Geophys. Res., 113, D13107, doi:10.1029/2008JD009957, 2008.

Muñoz, R. and Garreaud, R.: Dynamics of the low-level jet off the west coast of subtropical South America, Mon. Weather Rev., 133, 3661-3677, 2005.

Muñoz, R., Garreaud, R., Gallardo, L., Cabello, A., and Rosenbluth, B.: Mejoría del Conocimiento del Recurso Eólico en el Norte y Centro del País, Santiago: Universidad de Chile, 2003.

Narváez, D., Navarrete, S., Largier, J., and Vargas, C.: Onshore advection of warm water, larval invertebrate settlement, and relaxation of upwelling off central Chile, Mar. Ecol. Prog. Ser., 309, 159-173, 2006.

Nuss, W.: Synoptic-Scale Structure and the Character of Coastally Trapped Wind Reversals, Mon. Weather Rev., 135, 60-81, 2010.

Nuss, W. A., Bane, J. M., Thompson, W. T., Holt, T., Dorman, C. E., Ralph, F. M., Rotunno, R., Klemp, J. B., Skamarock, W. C., Samelson, R. M., Rogerson, A. M., Reason, C., and Jackson, P.: Coastally Trapped Wind Reversals: Progress toward Understanding, B. Am. Meteorol. Soc., 81, 719-743, 2000.

Painemal, D., Garreaud, R., Rutllant, J., and Zuidema, P.: Southeast Pacific Stratocumulus: High-Frequency Variability and Mesoscale Structures over San Felix Island, J. Appl. Meteorol. Clim., 49, 463-477, 2010.

Rahn, D. A. and Garreaud, R.: Marine boundary layer over the subtropical southeast Pacific during VOCALS-REx - Part 2: Synoptic variability, Atmos. Chem. Phys., 10, 4507-4519, doi:10.5194/acp-10-4507-2010, 2010a.

Rahn, D. A. and Garreaud, R.: Marine boundary layer over the subtropical southeast Pacific during VOCALS-REx - Part 1: Mean structure and diurnal cycle, Atmos. Chem. Phys., 10, 4491-4506, doi:10.5194/acp-10-4491-2010, 2010b.

Rahn, D., Garreaud, R., and Rutllant, J.: The low-level atmospheric circulation near Tongoy Bay / point Lengua de Vaca (Chilean coast, $30^{\circ} \mathrm{S}$ ), Mon. Wea. Rev., submitted, February 2011.

Ramp, S. and Bahr, F.: Seasonal Evolution of the Upwelling Process South of Cape Blanco, J. Phys. Oceanogr., 38, 3-28, 2008.

Ramp, S., Paduan, J., Shulman, I., Kindle, J., Bahr, F., and Chavez, F.: Observations of upwelling and relaxation events in the northern Monterey Bay during August 2000, J. Geophys. Res., 110, C07013, doi:10.1029/2004JC002538, 2005.

Renault, L., Dewitte, B., Falvey, M., Garreaud, R., Echevin, V., and Bonjean, F.: Impact of atmospheric coastal jet off central Chile on sea surface temperature from satellite observations (2000-2007), J. Geophys. Res, 114, C08006, doi:10.1029/2008JC005083, 2009.

Rogers, D. P., Dorman, C. E., Edwards, K. A., Brooks, I. M., Melville, W. K., Burk, S. D., Thompson, W. T., Holt, T., Ström, L. M., Tjernström, M., Grisogono, B., Bane, J. M., Nuss, W. A., Morley, B. M., and Schanot, A. J.: Highlights of Coastal Waves 1996, BAMS, 79, 1307-1326, 1998.

Rutllant, J. and Montecinos, V.: Multiscale upwelling forcing cycles and biological response off north-central Chile, Rev. Chil. Hist. Nat., 75, 217-231, 2002.

Smith, R. L.: Coastal upwelling in the modern ocean. Geological Society, London, Special Publications, 64, 9-28, 1992.

Smith, R. L., Huyer, A., Godfrey, J. S., and Church, J. A.: The Leeuwin Current off Western Australia, 1986-1987, J. Phys. Ocean., 21, 323-345, 1991. 
Strub, P. T., Mesias, J. M., Montecino, V., Rutllant, J., and Salinas, S.: Coastal ocean circulation off western South America, In The Sea, vol. 11, edited by: Robinson, A. R. and Brink, K. H., John Wiley and Sons, Inc., New York, 273-314, 1998?

Tapia, F., Navarrete, S., Castillo, M., Menge, B., Castilla, J., Largier, J., Wieters, E., Broitman, B., and Barth, J.: Thermal indices of upwelling effects on inner-shelf habitats, Progr. Oceanogr., 83, 278-287, 2009.

Wentz, F.: A well-calibrated ocean algorithm for special sensor microwave/imager, J. Geophys. Res, 102, 8703-8718, 1997.
Wood, R., Mechoso, C. R., Bretherton, C. S., Weller, R. A., Huebert, B., Straneo, F., Albrecht, B. A., Coe, H., Allen, G., Vaughan, G., Daum, P., Fairall, C., Chand, D., Gallardo Klenner, L., Garreaud, R., Grados, C., Covert, D. S., Bates, T. S., Krejci, R., Russell, L. M., de Szoeke, S., Brewer, A., Yuter, S. E., Springston, S. R., Chaigneau, A., Toniazzo, T., Minnis, P., Palikonda, R., Abel, S. J., Brown, W. O. J., Williams, S., Fochesatto, J., Brioude, J., and Bower, K. N.: The VAMOS Ocean-Cloud-Atmosphere-Land Study Regional Experiment (VOCALS-REx): goals, platforms, and field operations, Atmos. Chem. Phys., 11, 627-654, doi:10.5194/acp-11-6272011, 2011. 